\begin{tabular}{|c|c|}
\hline $\begin{array}{l}\text { ÇÜTAD } \\
\text { Çukurova Üniversitesi } \\
\text { Türkoloji Araștırmaları Dergisi }\end{array}$ & $\begin{array}{l}\text { Cilt 4, Sayı } 2 \\
\text { Aralık } 2019\end{array}$ \\
\hline $\begin{array}{l}\text { ISSN: } 2587-1900 \\
\text { E-ISSN: } 2548-0979\end{array}$ & $\begin{array}{l}\text { Geliş Tarihi: } 14.11 .2019 \\
\text { Kabul Tarihi: } 09.12 .2019\end{array}$ \\
\hline \multicolumn{2}{|c|}{$\begin{array}{l}\text { Makale Künyesi (Tanıtma): Dağıstanlıŏlu, B. E. (2019). M. Selcen } \\
\text { Çürük / Türkçede Olumsuzluk. [Türkçede Olumsuzluk Harezm Türkçesi } \\
\text { Örneği adlı kitap tanıtımı]. Çukurova Üniversitesi Türkoloji Araştırmaları } \\
\text { Dergisi. } 4 \text { (2), 527-531. }\end{array}$} \\
\hline
\end{tabular}

\title{
M. SELCEN ÇÜRÜK / TÜRKÇEDE OLUMSUZLUK
}

\section{B. Erdem DAĞISTANLIOĞLU ${ }^{1}$}

Olumsuzluk, dilin kavramsal sorgulanmasının içinde bilinen ilk örneklerden bu yana iletişimin, mantığın, felsefenin ve bu bağlamlarda dil biliminin inceleme sahasında yer alagelmiştir. Selcen Çürük, Türkçede Olumsuzluk Harezm Türkçesi Örneği başlığılla Kesit Yayınlarından Aralık 2018'de çıkan çalışmasında, olumsuzluk kavramının kapsamını, farklı disiplinlerden bu kavrama yönelik yaklaşımları, biçim esasında söz dizimi ve anlam bakımından Harezm Türkçesinde olumsuzluğun kurgulanışı ve ifade değerini ele almaktadır. Yazarın ana ve alt başlıkları 25 tablo, 9 şekille ayrıntılandırdığı 837 sayfalık bu çalışması, Prof. Dr. A. Deniz Abik danışmanlığında 2013 yılında tamamladığı doktora tezinden geliştirilmiş olup çalışmanın örneklemini Rabgûzî'nin Kısasü'lEnbiyâ'sı oluşturmuştur. Türkçede olumsuzluk, eserde art ve eş zamanlı tanıklarla karşılaştırmalı olarak ele alınmıştır. Çürük (2018), Kısasü'l-Enbiyâ tercihini eserin Harezm Türkçesini tek başına temsil etme gücüne sahip olmasına dayandırmıştır.

Türkçede Olumsuzluk Harezm Türkçesi Örneği kitabı; giriş, olumsuzluğa kuramsal bir bakış, Kısasü'l-Enbiyâ'da olumsuzluğun işaretlenmesi olumsuzluğun biçim-dizimsel karakteristiği ve Kısasü'lEnbiyâ'da olumsuzluğun biçim-anlamsal karakteristiği olmak üzere dört ana bölümün ardından bir sonuç ve değerlendirme bölümünü ihtiva etmektedir. Eserin sonunda açıklamalı kavram ve terimler sözlüğü ile Kısasü'l-Enbiyâ' 'nın olumsuzluk bütüncesi yer almaktadır.

Kitabın birinci bölümü olan giriş kısmında Rabgûzî'nin Kısasü'lEnbiyâ'sının konusu ve kapsamı hakkında bilgilere yer verilmiştir. Yazar, metni okuyup anlamlandırmada Boeschoten, Vandamme ve Tezcan (1995) ile Ata (1997)'nın yayınlarından faydalandığını, ayrıca

\footnotetext{
${ }^{1}$ Çukurova Üniversitesi, Eğitim Fakültesi, Türkçe Eğitimi Ana Bilim Dalı, Dr. Öğr. Üyesi erdemdgstn@gmail.com https://orcid.org/0000-0001-8763-1494
} 
Grønbech (1948)'in yayımladığı eserin Londra nüshasının tıpkıbasımından da istifade etttiğini belirtmiştir. Giriş bölümünde çalışmanın konusu olan olumsuzluk kavramının neden Kısasü'lEnbiyâ'dan tanık cümlelerle ele alındığı üzerinde durulmuştur. Yazıldığı yüzyıl göz önünde bulundurulduğunda Doğu Türkçesinin Nehcü'l-Ferâdîs ile birlikte iki önemli eserinden biri olan Kısasü'lEnbiyâ, yalnızca hacmi ve dil özellikleriyle öne çıkmamaktadır. Eserin metin kurgusu, içeriğine uygun biçimde tahkiye şeklinde tasarlanmış, Çürük'ün $(2018$, s. 28) de belirttiği üzere bu kurgu, betimlemelerden diyaloglara çok farklı yöntemin kullanıldığı dililetişim ilişkisi bakımından zengin bir metni doğurmuştur. Çürük (2018, s. 29); Hz. İbrahim, eşi Sâre ve melik Zü'l-arş bin Fâruku'lHamîrî arasındaki diyalogu 14. yüzyıl Doğu Türkçesinde bir ifade aracı olarak olumsuzluğun çok farklı biçimsel ve anlamsal tanığı olarak sunmuştur:

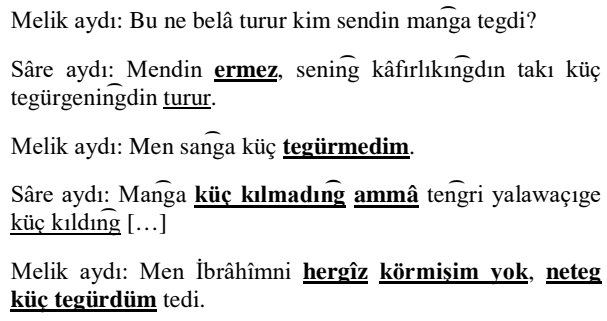

Sâre aydı: Bu İbrâhîm mening erim turur, meni andın adırdıng sanga bu belâ emgek ol sebebdin tegdi vd.

$\mathrm{Bu}$ alıntıda görüldüğü üzere, Kısasü'l-Enbiyâ özelinden 14. yüzyıl Doğu Türkçesinde biçim birimsel ve sözlüksel olumsuzluğu ele alan çalışmada metindeki olumsuzluk kavramı dil ekseninde biçimdizim ve biçim-anlam bağlamıyla ele alınmıştır. Tanık cümleler gerek çalışma içinde gerekse bütünce bölümünde yalnızca birer dizin ögesi veya madde tanığı olarak değil öncesi ve sonrasıyla anlam bütünlüğü oluşturacak biçimde, bağlamıyla sunulmuştur. Söz konusu cümleler yazılırken olumsuzluk işaretleyicileri koyu ve altı çizilerek, onlarla bağlantılı olumlu yapılar ise sadece altları çizilerek verilmiştir. Kitapta, olumsuzluğa yönelik Türkçe terim söz varlığının yazarın ilk kez kendi kitabında kullandığı biçimiyle sunulduğu görülmektedir. Bu terimler, kitabın sonundaki açıklamalı kavram ve terimler sözlüğü bölümünde İngilizce karşılıkları ve izahlarıyla belirtilmiştir.

Kitabın ikinci kısmı olumsuzluğa kuramsal bir bakış, mezkûr kavramı Aristo'dan itibaren farklı bilim alanları ve bakış açılarıyla 
nasıl ele alındığını inceleyen; yapı bilgisi, söz dizimi, anlam bilimi ve edim bilimi gibi farklı düzlemlerde biçim ve anlam yönüyle olumsuzluk üzerine yapılan çalışmaları değerlendiren, olumsuzluğa dair alanyazını ortaya koyan ve okuru çalışmanın bulgularına hazırlayan kapsamlı bir bölümdür. İnsanın ve dilinin ayırt edici özelliği olarak ele alınan olumsuzluğun olumlu ile ilişkisinin değerlendirildiği, birbirlerine yönelik çağrışım değerlerinin ve kapsayıcılıklarının sorgulandığg bu bölümde Türkiye Türkçesi örnekleriyle olumsuzluğun karmaşık yapısının bağlamla ne denli farklılıklar arz edebildiği, olumsuzluğun her seferinde belirli / beklendik bir olumluğa karşıt olmadığı ifade edilmiş, üzerinde çalışılan kavramın farklı disiplinlerde ne şekilde algılandığ 1 sorgulanmıştır. $\mathrm{Bu}$ çalışmada olumsuzluk felsefe ve mantıkta, dil biliminde (anlam biliminde), dil felsefesi ve edim biliminde farklı bakış açılarıyla ve geniş bir alanyazını bilgisiyle sorgulanmıştır. Ayrıca genelde dil özelde ise Türkçede kılınış ve görünüşle olumsuzluğun bağı ele alınmış, söz dizimi bakımından cümle olumsuzluğu ve öge olumsuzluğu irdelenmiştir. Türkçenin tarihî dönemlerinde yazılmış dil bilgisi içerir kitaplar ile Türkçenin tarihî dönemlerini ve/veya Türkiye Türkçesini ele alan dil bilgisi kitaplarının olumsuzluğu değerlendirme biçimlerini inceleyen bölüm, Çürük'ün eserinde verdiği kuram bilgisinin son kısmını teşkil etmektedir.

Kitabın çalışmadaki bulguların ortaya koyulduğu ve tartışıldığ bölümü olan inceleme, iki ana kısımdan oluşmaktadır: Kısasü'lEnbiyâ'da olumsuzluğun işaretlenmesi olumsuzluğun biçim-dizimsel karakteristiği ve Kısasü'l-Enbiyâ'da olumsuzluğun biçim-anlamsal karakteristiği. Her iki bölümün ortak özelliği, olumsuzluğun incelenmesinde yazarın biçim birim temelinde bir bakış açısını kullanmış olmasıdır.

Kitabın üçüncü bölümü olan Klsasü'l-Enbiyâ'da olumsuzluğun işaretlenmesi olumsuzluğun biçim-dizimsel karakteristiği'de veri, fiil olumsuzluğu, olumsuz yeterlik, isim olumsuzluğu, ne ve ne...ne ile olumsuz kutupluluk unsurları başlıkları altında incelenmiştir. Bu tasnifte göze ilk çarpan, fiil ve isim olumsuzluklarının dışına çıkarılmış olan olumsuz yeterlikdir. Çürük (2018, s. 331), yeterlik kavramının 14. yy. Doğu Türkçesinde olumlusu bakımından fiil tabanlı bir görünüm arz ettiğini belirtmiştir: $-A /-U$ bil- veya $-S A$ bol-. Yeterliğin olumsuzunu inceleyen yazar, bu kategorideki yapıların olumludan çok daha zengin biçim özelliklerine sahip olduğunu belirtmektedir: -A/-U bilme-, -sA bolma-, -UmA-, zarf-fiil + alma-, -p bolmas, -UrGA kuvveti yok, -mAKGA/-GUKA küçü/kudreti/kuvveti yetme-lyok vb. Olumsuz kutupluluk unsurları Kisasü'l-Enbiyâ'da 
sözlüksel ve deyimsel olarak iki başlıkta incelenmiştir: atını agzınga alma-, köngülge yakma-, kadgu yeme-, tili barma- (deyimsel); zînhâr, aslâ, hergiz, hîç, hîç vakt, kimerse, nerse,kamug (sözlüksel) vd.

Olumsuzluğun anlam boyutunda ele alındığı Klsasü'l-Enbiyâ'da olumsuzluğun biçim-anlamsal karakteristiği bölümü, çoklu olumsuzluk, Kısasü'l-Enbiyâ'da sezdirime dayalı olumsuzluk ve olumsuzluk-soru ilişkisi alt başlıklarından oluşmaktadır. Kısasü'lEnbiyâ'da çoklu olumsuzluğu iki ayrı biçimiyle tanıklayan Çürük (2018, s. 517) ister dil bilgisel olumsuzluk ögeleriyle ister içsel olumsuzluk (internal negation) ile oluşturulsun kurgulanan biçimde ya iki olumsuzluğun bir arada ve birbirini iptal ederek kullanıldığını ya da birbirlerini iptal etmeden olumsuz anlamı verdiklerini ifade etmiştir. Bir edim değeri olarak ele alınan sezdirime dayalı olumsuzluk konusu iki başlıkta değerlendirilmiştir: konuşma sezdirimleri (conversational implicature) ve uzlaşmaya dayall sezdirimler (conventional implicature). Yazar, Kısasü'l-Enbiyâ'da her iki başlığa dair tanıkların bulunduğunu belirtmiş ve metnin olumsuzluk kavramı bakımından ifade zenginliğini ortaya koymuştur.

Türkçede olumsuzluk kavramına dair alanyazınını değerlendiren yazar, olumsuzluğun genellikle fiil çekimi etrafinda değerlendirildiğini ve bu bağlamda cümleye dair algılandığını belirtmiş, Kısasü'l-Enbiyâ tanıklarıyla ele aldığı bu konuyu yalnızca bir fiil ögesi olarak değil yokluğu / bulunmamayı da içeren fiil ve isim ulamları olarak geniş bir çatıda incelemiştir. Ayrıca bu çalışmada olumsuzluğun içinde yer aldığı metin bağlamı gözetilerek gerek tanıklarda gerekse onların izahlarında olumlu diğer ilişkili birimlerle bağı açıklanmaya çalışılmıştır.

Çalışmanın okuyucu merakını zedelemeden dillendirilebilecek vargılarından biri, diğer dillerde olduğu gibi Türkçede de biçim-söz dizimi bakımından olumsuzluğun işaretleyiciler odağında kurgulandığı bilgisidir. Bu bağlamda, çalışmada olumsuzluğun diğer dillerde olduğu gibi genelde Türkçede özelde Kısasü'l-Enbiyâ'da şu koşullarla tasarlandığı sonucuna varılmıştır: 1. standart/fiil olumsuzluk(u) (standart negation) -mA- 2. Fiil-dışı olumsuzluk (nonverbalnegation) ermes "değil", $+{ }_{s X z} 3$. Varlık olumsuzluğu (existential negation) yok. Çalışmanın örneklemini oluşturan Kısasü'lEnbiyâ'da hem dizim hem de anlam bakımından iletişim değeriyle olumsuzluğa hizmet eden biçim birimlerden -mA-, +sXz, ermes vd. ögelerin türlü işlevlerle saptanması; içsel olumsuzluk taşıan sözlüksel birimlerin, olumsuz kutupluluk ögelerinin, retorik sorularla var edilen sezdirmeli olumsuzluklar ile yüzey ve derin yapıdaki olumlu ve olumsuzun uyumlu ve zıtlık arz edecek biçimde kullanımlarının, $a c ̧ ı$ - 
örtük olumsuzluğun farklı ve çok sayıda örneğinin tespit edilmesi yazarı, eserin dönemini temsil gücünü ispata kâfi olduğu sonucuna ulaştırmıştır.

Türkçede Olumsuzluk Harezm Türkçesi Örneği başlıklı çalışmada, yazarın olumsuzluk kavramı hakkında Türkiye Türkçesi esasında ortaya koyduğu alanyazını bilgisi, bağlam esaslı bu çalışmada tanıkların yalnızca ilgili biçim birimle verilmeyip bütünlük gözetilerek sunulması, Kısasü'l-Enbiyâ tanıkları özelinden Türkçenin tarihî ve çağdaş dönemlerine uzanan vargıları, Türkçe dışındaki alanyazınını Türkçeye aktarması ile konu hakkında ilk defa kendi eserinde gösterdiği terim önerileri, bu terimlerin tanımlarını ve İngilizce karşılıklarını içeren sözlük bölümü göz önünde bulundurulduğunda kapsamlı bir eserin Türk dünyası araştırmalarına kazandırıldığı söylenebilir. Yazarın metin içi kısaltma alışkanlıklarına okurun alışma süreci bir yana bırakılırsa akademik bir yayında çokça ihtiyaç duyulan akıcı ve takip edilebilir anlatım biçimi, eserin okunmasını kolaylaştırmaktadır.

\section{KAYNAKÇA}

Ata, A. (1997). Kısasü'l-Enbiya (Peygamber kıssaları) I giriş-metintıpkıbasım. Ankara: Türk Dil Kurumu Yayınları.

Boeschoten, H. E., O’Kane, J. ve Tezcan, S. (1995). Al-Rabghuzi the stories of prophets, Qisas al-Anbiya an Eastern Turkish version vol. I. Leiden-New York-Köln: E. J. Brill.

Çürük, S. (2018). Türkçede olumsuzluk Harezm Türkçesi örneği İstanbul: Kesit Yayınları.

Grønbech, K. (1948). Rabghuzi narrationes de prophetis cod. mus. Brit. add. 7851 reproduced in facsimile with an introduction. Copenhagen: E. Munksgaard. 